\title{
Immune mechanisms in atherosclerosis, especially in diabetes type 2
}

\section{Johan Frostegård *}

Unit of Immunology and Chronic Disease, Institute of Environmental Medicine, Karolinska Institutet, Stockholm, Sweden

\section{Edited by:}

Gabriel Virella, Faculdade de

Medicina, Universidade de Lisboa,

Portugal

Reviewed by:

Susanna Hofmann, University of Cincinnati, USA

Gabriel Virella, Universidade de

Lisboa, Portugal

*Correspondence:

Johan Frostegård, Unit of

Immunology and Chronic Disease, Institute of Environmental Medicine

Karolinska Institutet, Scheeles v1,

17177 Stockholm, Sweden

e-mail: johan.frostegard@ki.se
Atherosclerosis and ensuing cardiovascular disease (CVD) are major complications of diabetes type 2. Atherosclerosis is a chronic inflammatory condition involving immunocompetent cells of different types present in the lesions. Even though inflammation and immune activation may be more pronounced in atherosclerosis in diabetes type 2, there does not appear to be any major differences between diabetics and non-diabetics. Similar factors are thus implicated in atherosclerosis-associated immune activation in both groups. The cause of immune activation is not known and different mutually non-exclusive possibilities exist. Oxidized and/or enzymatically modified forms of low-density lipoprotein (OxLDL) and dead cells are present in atherosclerotic plaques. OxLDL could play a role, being pro-inflammatory and immunostimulatory as it activates T-cells and is cytotoxic at higher concentrations. Inflammatory phospholipids in OxLDL are implicated, with phosphorylcholine (PC) as one of the exposed antigens. Antibodies against PC (anti-PC) are anti-atherogenic in mouse studies, and anti-PC is negatively associated with development of atherosclerosis and CVD in humans. Bacteria and virus have been discussed as potential causes of immune activation, but it has been difficult to find direct evidence supporting this hypothesis, and antibiotic trials in humans have been negative or inconclusive. Heat shock proteins (HSP) could be one major target for atherogenic immune reactions. More direct causes of plaque rupture include cytokines such as interleukin $1 \beta$ (IL-1 $1 \beta)$, tumor necrosis factor (TNF), and also lipid mediators as leukotrienes. In addition, in diabetes, hyperglycemia and oxidative stress appear to accelerate the development of atherosclerosis, one mechanism could be via promotion of immune reactions. To prove that immune reactions are causative of atherosclerosis and CVD, further studies with immune-modulatory treatments are needed.

Keywords: atherosclerosis, immune system, natural antibodies, phospholipids, inflammation

\section{BACKGROUND}

Type 2 diabetes represents a major and growing problem throughout the world, not only in so-called developed countries. In addition to nephropathy and microvascular disease, cardiovascular disease (CVD), and accelerated atherosclerosis often occur in diabetes, both type 1 and $2(1-3)$. The main focus of this review is immune activation in atherosclerosis, especially in type 2 diabetes.

The link between type 2 diabetes and inflammation is well established, and there are signs of chronic inflammation in both diabetes and insulin resistance (IR), a typical feature of type 2 diabetes (4). Also in atherosclerosis and CVD, chronic inflammation is a major feature, and in atherosclerosis, activated immune competent cells such as T-cells and antigen-presenting cells, are abundant in lesions (5).

Even though inflammation and size of the necrotic core may be increased in atherosclerosis in diabetes $(6,7)$, there was no difference in the prevalence of macrophages, lymphocytes, and overall inflammation in plaque or in the atherosclerotic cap between diabetics and non-diabetics according to the largest study in this area (8). It thus appears that there is no known fundamental difference between the immune activation and inflammation present in atherosclerosis among non-diabetics as compared to diabetics. Still macrophages and surface thrombi may persist longer after ischemic symptoms in diabetes, which could contribute to the increased risk of recurrent CVD in this condition (8) and risk factors as hyperglycemia naturally play a special role. In this review, I therefore discuss immune activation in atherosclerosis in general and in diabetes type 2 in the same context.

Acute inflammatory response developed from an evolutionary point of view most likely to protect against pathogens and to repair tissue damage, which could be caused also by trauma. The classic symptoms of acute inflammation - pain, swelling, redness, heat, and decrease of function - were described already in Hippocratic medicine. When acute inflammation is not resolved, but instead persists and becomes chronic, it can become a major problem. Indeed chronic inflammatory conditions represent a major disease burden in the western world, and increasingly, also in developing countries (9). Examples of chronic inflammatory diseases include rheumatic diseases such as rheumatoid arthritis (RA) and systemic lupus erythematosus (SLE); atherosclerosis and its major consequence, CVD including myocardial infarction (MI), acute 
coronary syndrome (ACS), claudication, and stroke; Alzheimer's disease; diabetes type 2; increased IR and even abdominal obesity and osteoarthritis have inflammatory components (9).

Associations between these conditions are well known. For example, type 2 diabetes is a major risk factor for atherosclerosis and CVD (together with smoking, hypertension, dyslipidemia, age, and male sex) (10). Alzheimer's disease and atherosclerosis and/or CVD have some risk factors in common (11) and smoking is a risk marker for RA in addition to well known effects in CVD (12). It has also become clear that there are associations between rheumatic diseases and atherosclerosis/CVD, especially in SLE (13). Also in $\mathrm{RA}$, there is an increased risk of CVD according to many reports, and a recent meta-analysis imply that atherosclerosis per se is more prevalent in patients in RA (13-15). It is interesting to note that there are reports which also describe an increased risk of type 2 diabetes in RA (16).

Anti-inflammatory treatments have improved the prognoses of many patients in chronic inflammatory conditions, the most notable example being biologics such as tumor necrosis factor (TNF)-inhibitors in RA and other autoimmune conditions (9). There is therefore an apparent need to evaluate targeted anti-inflammatory and immunomodulative treatments in other chronic inflammatory conditions.

An interesting possibility would be that biologics such as TNFinhibitors could be therapeutically effective in atherosclerosis and diabetes type 2 and their complications. However, this does not appear to be the case to any significant degree. Although systemic blockade of TNF has an anti-cachectic effect in RA patients, the data on anti-TNF effects of IR are conflicting, depending on disease severity and degree of inflammation (17-19). Still, a recent case report indicates that treatment with a novel T-cell inhibitor had a dramatic effect on IR in RA (20).

As discussed in an editorial (14), it is interesting to note that inflammatory nature of atherosclerosis was known already 180 years ago, reported by the famous Austrian pathologist K. Rokitansky. R. Virchow confirmed these findings somewhat later, and the ensuing debate between these two giants in the history of medicine is of interest also now $(21,22)$. Rokitansky argued that atherosclerosis is secondary to other disease processes and phenomena, while Virchow supported the view that inflammation in atherosclerosis is a primary pathogenic factor $(21,22)$. Both could be right, since atherosclerosis is nowadays recognized as an inflammatory process, and could be secondary to other inflammatory conditions.

A role of the immune system in atherosclerosis, with or without background of diabetes type 2, has been suggested since the 1980s, when activated T-cells were detected in human atherosclerotic lesions (23). Since then, an array of data indicate that immune activation is a major feature of and plays a role in atherosclerosis, and also that immunomodulation to ameliorate disease development could be an interesting possibility $(10,24,25)$.

At an early stage of atherosclerosis, macrophages accumulate and become filled with lipids, mainly derived from modified forms of low-density lipoprotein (LDL). These lipid-filled macrophages develop into foam cells, and subsequently, these and other cells die, creating a necrotic core of cell debris. An organized apoptotic clearance, is thus not effective in advanced atherosclerotic lesions. Also lymphocytes, especially T-cells, are common at a very early stage of disease development. In the 1990s, it was demonstrated that immunomodulation can change the course of atherosclerosis development; while administration of heat shock protein 60/65 accelerated atherosclerosis development (26), immunization with oxLDL, had the opposite effect (27).

However, it should be noted, that there may be important differences between animal models and human disease in this context (28). Even though mouse models of atherosclerosis have very much increased our understanding of atherosclerosis it is still interesting to note that there may be problems with translating mouse data to humans. For example, lipid levels are strikingly much higher in mice models, and another problem is that it is difficult to mimic human CVD in animal models, including mice models $(29,30)$. In this review, I have therefore chosen to emphasize data on immunity and atherosclerosis which are derived from human studies, including ex vivo and cohort studies.

As discussed in a previous review (24), available evidence indicates that atherosclerosis per se is a normal part of human aging, though its complications may not be part of the normal aging process, at least not to the same extent.

A direct causative role played by T-cells is suggested by animal experiments, with transfer of beta(2)-glycoprotein Ireactive lymphocytes, which enhanced early atherosclerosis in LDL receptor-deficient mice (31). Further, CD4+ T cells reactive to modified low-density lipoprotein aggravate atherosclerosis (32). An immunomodulatory role of T-cells is suggested by experiments where regulatory $\mathrm{T}$ cells suppress immune activation and thereby inhibit atherosclerosis (33). Interestingly, also NK T-cells may play a role in this context since CD1d-dependent activation of NKT cells aggravates atherosclerosis (34). Relatively little is known about the role of T-cells in human atherosclerosis, but it is interesting to note that Th17/Th1 imbalances have been reported, which may be related to plaque rupture $(35,36)$. Interestingly, data in humans and mice provide support for the concept that TH17 cells induced upon TGF-b signaling promote the development of cap structures in atherosclerotic plaques and the role of T-cells could depend on the local activation pattern and milieu (37). Clearly, the role of Tcells in plaque rupture is complicated. Further, subsets of Tlymphocytes with pro-atherogenic and plaque-destabilizing properties are increased in diabetes type 2 and associated with a worse CVD-outcome (38).

During recent years, a more detailed picture also of other inflammatory and/or immune competent cells has emerged from in vivo and other experimental studies, which need to be corroborated in human disease.

One example is dendritic cells (DC) which are specialized antigen-presenting cells, which may play an important role in the initiation and progression of atherosclerosis (39). DC are present in immature forms in the arterial wall and become activated during atherogenesis. In human atherosclerosis, DC are present both at an early stage (40) and late stage, with higher numbers in vulnerable plaques (41). Similar findings have been reported in 
mice, where DC may promote atherogenesis (42). Further, DC and T-cells co-localize in plaques (43).

Monocytes/macrophages are present in lesions at different stages of atherosclerosis. Macrophages play a major role in inflammatory responses and may alter their phenotype which may vary on a scale, from pro-inflammatory M1 to anti-inflammatory M2 macrophages. Interestingly, even though the whole spectra of macrophages are present in lesions, including the relatively inert and surprisingly long lived macrophage-derived foam cells, M1 cells are prevalent in the vicinity of plaque rupture $(44,45)$.

Another cell type common in atherosclerotic lesions with inflammatory and potentially immune-modulatory properties is mast cells (46). A significant role played by this cell type in atherosclerosis and its complications is suggested by a recent report, where it is demonstrated that intraplaque mast cell numbers associate with future cardiovascular events (47).

Even though some B-cells, neutrophils, and NK-cells are present in lesions, it is not known to what extent they play a major role (10).

The role of the immune system in human atherosclerosis with or without background of diabetes type 2 is less defined as compared to the relevant animal models. T-cell reactive to OxLDL and related lipids are present in blood and atherosclerotic plaques $(48,49)$, patients with autoimmune diseases have increased atherosclerosis (13), and aspects of humoral immunity as natural antibodies against phosphorylcholine (PC) and other antigens are associated with atheroprotection (50). Humoral immunity has been shown to have pathogenic consequences in type 1 diabetes, triggered by immune complexes containing oxidized forms of LDL (51).

Available data thus imply that the immune system plays a major role in atherosclerosis, which could be seen as a chronic inflammatory disease or disease process. Interestingly, also diabetes, IR abdominal obesity, and the metabolic syndrome also have important inflammatory components.

\section{DIABETES AND CAUSES OF IMMUNE ACTIVATION IN ATHEROSCLEROSIS}

The key question herein is to elucidate what is the direct cause of the immune reactions in atherosclerosis, in general and in diabetes, and also how the inflammatory disease process can be influenced. There are several major hypotheses, non-mutually exclusive.

OXIDATION AND OTHER MODIFICATIONS OF LDL AND OTHER MOIETIES Low-density lipoprotein can be modified by oxidation and/or enzymatic modification phospholipases being one example. LDL is also normally present in tissues as the intima of arteries, where it can bind to the proteoglycan matrix especially after modification. This binding is thought to be an early event in atherogenesis according to the "response to retention" hypothesis $(52,53)$.

Oxidized low-density lipoprotein has pro-inflammatory and immune-activating properties, activating endothelial cells, monocytes/macrophages, and $\mathrm{T}$ cells $(49,54,55)$. OxLDL also toxic at higher concentrations and an important feature of atherosclerotic lesions, perhaps somewhat understudied, is the abundance of dead cells. It is thus possible that OxLDL is one cause of such cell death $(49,54,55)$. Enzymatically modified LDL could play a major role, and PLA2, which causes such modification, is expressed in both normal arteries and atherosclerotic lesions (56) and can induce activation of DC (57). Inflammatory phospholipids such as lysophosphatidylcholine (LPC) and/or platelet activating factor (PAF)-like lipids cause much of OxLDL:s effects which can occur through the PAF-receptor (58-61) or other mechanisms including Toll-like receptor- and scavenger receptor-interaction $(62,63)$.

In general oxidized phospholipids (OxPL) are implicated in immune reactivity in atherosclerosis, and could be derived from LDL-modification but also from cell membrane changes. Such oxPL include LPC, and often, a shortened sn-2 position in the fatty acid moiety serves as a danger-associated molecular patterns (DAMP). Oxidation turns OxPLs into markers of modified self, which are recognized by both soluble and cell bound receptors such as scavenger receptors, natural antibodies, and also C-reactive protein (CRP). The common theme in these different system is likely to be removal of senescent and dead cells, but also oxidized or otherwise modified lipoproteins. This has been described in several recent publications $(62,64-69)$.

Another important example of DAMP, in addition to PC and oxPL epitopes, is malonyl-dialdehyde (MDA) which is also generated during LDL-oxidation. MDA forms adducts on proteins, carbohydrates, and DNA (63).

Other compounds which could be implicated as atherogenic in OxLDL are modified and/or oxidized forms of apoB and cholesterol. Such modified compounds may play a role but the underlying mechanisms need to be better defined $(63,70)$. Clinical studies support the hypothesis of inflammatory phospholipids as causes of atherosclerosis, whereas levels of OxLDL are raised in the metabolic syndrome (71), in hypertension (72) and in established type 2 diabetes (73). Further, high levels of MDA-LDL in isolated immune complexes predict future MI and acute CVD events in patients with type 2 diabetes (74).

Many epidemiological studies demonstrate that smoking is associated with atherosclerosis and $\operatorname{CVD}(75,76)$ and animal experiments demonstrate that smoking promotes atherogenesis (77-79). Somewhat surprisingly, underlying mechanisms are not fully clarified. Still, one mechanism is smoking-induced increased lipid-oxidation (80) and closely related to this, oxidative stress (81). Smoking is associated with systemic and local inflammation with raised levels of pro-inflammatory cytokines and cells, in particular in chronic obstructive pulmonary disease (82), which could play a role also in atherosclerosis.

Additionally, several factors appear to be diabetes-specific and able to further aggravate atherosclerosis (and CVD) among diabetics. One major such factor is reduction of endothelial nitric oxide (NO)-levels, leading to deterioration of endothelial function, an early sign of vascular problems and increased risk of atherosclerosis and CVD. Hyperglycemia per se leads to increased levels of reactive oxygen species, which in turn inactivate $\mathrm{NO}$ and thus impair endothelial function. One common denominator is the formation of advanced glycation end products (AGEs) which have pro-inflammatory and potentially atherogenic properties (83-88). Interestingly, atherosclerosis is suppressed by the soluble receptor 
for AGEs in an animal model (89). Also susceptibility of LDL and its subfractions to glycation could play a role, in diabetes type 2 (90) AGE-products of LDL are able to generate autoantibodies, which on the other hand appear to have pro-inflammatory properties (91). Another interesting connection between AGEs and OxLDL are previous findings where AGEs initiate LDL oxidation (92). Further, increased oxidation of LDL in diabetes could promote atherogenesis $(73,93)$.

Other potential underlying factors are present in type 2 diabetes, but where the connection to immune reactivity in atherosclerosis is less clear, and thus not a focus herein. These include increased circulating free fatty acids in patients with abdominal obesity, which could be atherogenic by decreasing HDL-levels, increasing levels of small dense LDL and also by a negative effect on endothelial function $(3,94)$. Other mechanisms include effects on smooth muscle cells, such as induction of apoptosis and thus plaque instability (95) and also a hypercoagulative state by alterations in platelet function (96).

\section{AUTOANTIBODIES AND IMMUNE COMPLEXES RELATED TO PHOSPHOLIPID EPITOPES AND OxLDL}

An interesting possibility is that immune complexes containing OxLDL could contribute to vascular damage by promoting inflammation and atherosclerosis, which has been reported in type 2 diabetes $(97,98)$. In addition to oxLDL, also MDA-LDL and AGEproduct-modified LDL induce immune responses in humans (99). The role of antibodies against these different forms of modified LDL is less clear, and varies in different studies: both negative and positive associations have been described. This could depend on different methods used, different degrees of oxidation and also on different immunoglobulin subclasses and isotypes. On the other hand, the antigenic constitution of immune complexes formed with modified forms of LDL and their corresponding antibodies may influence their pathogenicity, as suggested by the recent observation that high levels of highly oxidized forms of LDL (MDA-LDL) in isolated IC predict future MI and acute CV events in patients with type 2 diabetes (74).

It is also possible that there are differences between mouse and man which could be the basis for the conflicting views about the pathogenic or protective role of the antibody response to modified forms of LDL (100, 101).

Another type of antibodies that has attracted attention are those against PC (anti-PC), which are often considered as "natural" antibodies. We have reported in several publications that anti-PC is a protection marker for atherosclerosis development and CVD, in different populations, both healthy individuals, ACS patients, and patients with SLE or RA $(50,102-107)$. Animal experiments also support a protective role of anti-PC. Immunization with pneumococci containing PC induced a decrease in atherosclerosis development in a mouse model in parallel with an increase in anti-PC, among other antibodies (108). Passive and active immunization raising anti-PC levels decrease atherosclerosis in mouse models $(109,110)$.

Human anti-PC could be anti-atherogenic and decrease risk of CVD by anti-inflammatory effects (107), inhibition of oxLDLuptake through scavenger receptors (111) and inhibition of LPCinduced cell (112). In mouse models, the anti-inflammatory effect of anti-PC was confirmed, and facilitating phagocytosis was reported as one mechanism. Anti-PC antibodies bind dead and dying cells, enhancing their phagocytosis and clearance (113). Further investigations are necessary to determine whether the data generated in animal models translates to human medicine.

A Western life style could play a role to influence anti-PC levels, and one underlying factor could be infections which are not prevalent in developed countries $(114,115)$. Gluten in the diet could also play a role being a novel component of human diet from an evolutionary point of view (116). The heritability of anti-PC is $37 \%$, allowing also for genetic factors (117). In line with these findings, a recent report indicates that antibodies against reactive a-dicarbonyls such as methylglyoxal (MGO) are negatively associated with atherosclerosis development among patients with diabetes type 2 . This finding suggests an additional role played by diabetes type 2 immune reactivity in atherosclerosis development as compared to the general population (118). Still, it is interesting to note that MGO-LDL is only weakly immunogenic in humans (119). Clearly, further research is needed to clarify the role by AGE-recognizing antibodies in diabetes type 2 and atherosclerosis.

A potential role of epigenetic changes in both atherosclerosis/CVD and type 2 diabetes is not the topic of this review, though a very interesting subject. One can not exclude that epigenetic mechanisms may influence immune mechanisms in both these conditions. In an intriguing study, it was recently demonstrated that in an atherosclerosis mouse model, maternal immunization with oxidized LDL affects in utero programing of both atherosclerosis and IR and type 2 diabetes, promoting protection against development of these conditions (120) Whether this can be translated to humans also remains to be demonstrated.

\section{HEAT SHOCK PROTEINS}

Antibodies against heat shock proteins (HSPs), especially HSP60/65 but also others like HSP70 and HSP90 have been described as potential causes of atherosclerosis and CVD. HSPs are immunogenic, and T-cell clones recognizing HSP60 are present in atherosclerotic plaques $(121,122)$. HSPs may activate immune reactions through cross-reactivity with HSP from microorganisms as bacteria. This is supported by both clinical data with associations between antibodies against HSP60/65 and atherosclerosis, and experimental data where immunization with HSP 60/65 increases atherosclerosis in an animal model $(26,123)$.

We hypothesized that hypertension possibly could cause and immune reaction and inflammation in arteries by induction of HSP 60/65, which are also induced by oxLDL $(124,125)$ and in principle, in conditions such as diabetes, where LDL-oxidation is implicated, this could further enhance the progression of atherosclerosis.

\section{INFECTIONS}

Infections have since long been hypothesized to be a cause of atherosclerosis. Many pathogenic candidates have been proposed, one not excluding another. Chlamydophila pneumoniae (CP); periodontal organisms including Porphyromonas gingivalis (PG) and Aggregatibacter actinomycetemcomitans (AA); Helicobacter pylori (HP) and Cytomegalovirus (CVM) are among the most promising 
candidates, since they are present in plaques, promote atherosclerosis in animal studies, and have associations with disease in humans (126).

Early studies demonstrated presence of $\mathrm{CP}$ in atherosclerotic plaques (127) and that antibodies against $\mathrm{CP}$ were associated with CVD (128-130) but later also negative studies were published (126).

However, treatment with CP-targeting antibiotics had no effect on atherosclerosis (131-133). This clearly argues against CP as a causative agent, though there could be other explanations, for example, $\mathrm{CP}$ is difficult to reach within the plaque and thus it is still possible that at the earlier stages of CP-infection antibacterial treatment could be beneficial (126).

Periodontal pathogens, as $\mathrm{PG}$ and $\mathrm{AA}$, are also interesting pathogenic candidates. The association with periodontitis and $\mathrm{CVD} /$ atherosclerosis has been debated since there are confounders, including social ones, which may be difficult to control for. A recent statement from the American Heart Association supports an independent association between periodontal disease and atherosclerosis, but available data do not prove causation, even though it is interesting that intervention does decrease systemic inflammation and improves endothelial function (134).

Still it is interesting that periodontitis and diabetes could be related to each other, and in principle, periodontitis could be diabetogenic and then also increase the risk of atherosclerosis and CVD, while diabetes could increase the risk of periodontitis (135-137).

An inherent problem with viral infections such as CMV from the Herpes virus group is that they are very common, thus making the interpretation of any associations with diabetes, atherosclerosis or CVD complicated. It may be that certain patients subgroups that are prone to accelerated atherosclerosis and CVD, as it is seen for example after organ transplantation, CMV infection plays an important role (138). CMV is present in atherosclerotic lesions in many but not all studies (126), but also in healthy arteries (139) so in principle CMV could be just an innocent by-stander. However, CMV induces migration of arterial smooth muscle cells in vitro, suggesting potential pro-atherogenic mechanisms (140).

Helicobacter pylori infection, causing gastritis and gastric ulcer, may be implicated as supported by indirect evidence, where reduction of CVD after eradication of HP was reported $(126,141)$. However, no viable HP had been isolated from atherosclerotic plaques, and mouse experiments in general do not support a pathogenic role of HP in atherosclerosis (142).

Other pathogens including HIV, EBV, influenza virus, Mycoplasma pneumoniae and Streptococcus pneumoniae have also been discussed, but as of yet there is no conclusive causative evidence available (126). Borreliosis caused by spirochetes, is independently associated with CVD, although little is known from atherosclerosis-related experimental studies (143).

It is not clear if infections on the diabetic background contribute more to atherosclerosis, but it is interesting to note that an increased rate of infections with Chlamydia pneumoniae has been reported in patients with diabetes type 2 (144).

Taken together, even though the infection hypothesis in atherosclerosis with or without diabetes type 2 is very interesting and is supported by circumstantial evidence, there is still little direct evidence of a potential causative or pathogenic role of microorganisms in CVD/atherosclerosis. However, we can not exclude a possibility that infectious agents act in concert with diabetes-specific factors to promote atherosclerosis.

Infections could also be of importance indirectly. Many pathogens are present in lesions, and could start or promote an ongoing local inflammatory process which could lead to increased atherosclerosis and, in principle, also to CVD and plaque rupture at such sites, the local inflammation appears to be especially strong (5). Also the total infectious burden is associated with increased atherosclerosis and CVD, and the risk of infection is raised in diabetes, especially when blood glucose levels are not well controlled. Platelet aggregation and endothelial dysfunction, could also influence atherogenesis in this context $(126,145)$.

\section{OTHER TYPES OF IMMUNE ACTIVATION IN DIABETES TYPE 2 AND ATHEROSCLEROSIS}

Another potential link between atherosclerosis and diabetes type 2 , and thus also hyperglycemia and metabolic dysfunction, is provided by a recent study, where NKG2D, an immune-activating receptor expressed by different types of immune cells was tested (146). The authors reported that blocking NKG2D in apolipoprotein E-deficient (apo $\mathrm{E}^{-/-}$) mice led to a dramatic reduction in plaque formation, suppressed systemic and organ-specific inflammation, and improved abnormal metabolic conditions. Thus the NKG2D/ligand interaction could drive both: inflammation related to metabolic dysfunction/diabetes type 2 and atherosclerosis. Further, the molecules and pathogens discussed earlier such as OxLDL, HSPs, AGEs, and infectious agents, could upregulate NKG2D on different cell types, which in turn can activate T-cells, NK, and NKT cells and thus promote atherosclerosis; also other cell types as endothelial cells could produce pro-atherogenic factors, including cytokines (146).

It is well known that inflammation is a link between IR, obesity, and diabetes. Further abdominal obesity and IR are classic features of type 2 diabetes (147).

There are many examples of links between inflammation in other conditions and atherosclerosis. Periodontitis is also a systemic inflammatory condition, which is more frequent in patients with diabetes, could increase the risk of atherosclerosis and CVD also indirectly (137).

Raised levels of CRP is a risk marker for atherosclerosis and CVD in many studies, though it is not clear if CRP is either protective or detrimental for disease development. Cytokines as IL-6 and raised systemic levels of OxLDL are other examples of proinflammatory molecules that are associated with increased risk of CVD and atherosclerosis (10). Another group of inflammatory compounds that are present in advanced atherosclerotic plaques are lipid mediators, such as leukotrienes $(148,149)$.

Another example of associations between systemic inflammation and atherosclerosis and CVD is a number of autoimmune diseases. The evidence is strongest for SLE, where the risk of CVD is very high $(13,14,150)$. Also in RA and other types of autoimmune conditions, atherosclerosis is increased according to many studies including a recent meta-analysis (13-15). 


\section{TREATMENT AGAINST INFLAMMATION AND IMMUNE ACTIVATION TO AMELIORATE ATHEROSCLEROSIS, DECREASE RISK OF CVD, ESPECIALLY IN DIABETES OPTIMAL DIABETES TREATMENT}

Since diabetes type 2 is an inflammatory condition, first and foremost, control of the disease itself is likely of major importance for amelioration of pro-atherogenic inflammation and immune reactions. The specific optimal range of glycemic control in relation to CVD and atherosclerosis is still debated (151). This is similar to the situation in rheumatic diseases, where at least for RA, the risk may be similar to that in type 2 diabetes and where disease controls appears to be of importance (13).

\section{STATINS}

Statins were developed to treat hyperlipidemia and are often used in diabetes, though there is still some controversy about their exact role in this condition (152). Interestingly, statins have additional anti-inflammatory effects rather than simply decreasing cholesterol levels, which could be of major importance in atherosclerosis and CVD, not least in diabetic patients. These properties could be seen as "side-effect" of HMG CoA-reductase inhibition. Interestingly, statins have immunomodulatory properties, such as impairment of CD1d-mediated antigen presentation through the inhibition of prenylation (153) and decreasing MHC class II interaction with antigen (154). Further, the lipid-lowering effect of statins could by itself influence the immune reactions to LDL-related antigens, since a decrease in LDL-levels is likely to decrease also exposure of the immune system to modified forms of LDL, thus reducing the intensity of the corresponding immune response.

The Jupiter study demonstrated that statin treatment may be beneficial for individuals with increased high sensitivity CRP but normal LDL and it is possible that the beneficial effects of statins to some extent are in fact caused by their anti-inflammatory and immune-modulatory properties $(155,156)$.

\section{ANTI-INFLAMMATORY TREATMENT}

Even though the major focus of this review is immune activation it is still interesting to discuss this in the context of inflammation in general, especially in relation to treatment. There is as yet no established anti-inflammatory treatment of atherosclerosis or CVD, with or without diabetes. There are several interesting possibilities that are currently being investigated. In RA, treatment with methotrexate weekly is a very common schedule, and a recent meta-analysis demonstrate that the risk of CVD is decreased in patients with RA treated with methotrexate (157). Animal studies show that methotrexate decreases atherogenesis (158). In the cardiovascular inflammation reduction trial (CIRT) low dose methotrexate (target dose $20 \mathrm{mg} / \mathrm{week}$ ) is tested for reduction of CVD events among post-MI patients with diabetes or metabolic syndrome (156). There are different opinions about whether biologics as anti-TNF are beneficial from a cardiovascular point of view, though a recent study where decrease of CVD was reported in RA adds support to this possibility (159, 160). The Canakinumab Anti-Inflammatory Thrombosis Outcomes Study (CANTOS) investigates interleukin-1 $\beta$ (IL-1 $\beta$ ) inhibition and reduced risk of $\mathrm{MI}$, stroke, and CVD in stable coronary artery disease patients with persistent elevations of CRP $(\geq 2 \mathrm{mg} / \mathrm{L})(156,161)$.

Other interesting anti-inflammatory treatments could be inhibition of inflammatory lipid mediators as PAF (162). Annexin A5 is anti-thrombotic plasma protein, which is anti-inflammatory, inhibits atherosclerosis development and improves endothelial function in a mouse model (163). Annexin A5 could thus be a possible therapy candidate. Inhibition of phospholipases as treatment in patients after ACS are currently in trials (164).

\section{IMMUNOMODULATORY THERAPY}

Studies in mid-90s demonstrated that immunization with modified forms of LDL ameliorated atherosclerosis in animal models (27), providing initial evidence for immunomodulation as a potential treatment against atherosclerosis. One line of treatment is to target the apoB components which decreases atherosclerosis development in animal models $(70,165)$. However, such treatment did not show positive expected effect in humans (166), though the possibility that the end points used in this study where not optimal cannot be excluded.

Another possibility is that the phospholipid moiety on OxLDL could be the basis of immunomodulation, one example being PC. This is supported by clinical studies, animal and in vitro experiments (50). As discussed, mechanisms include anti-inflammatory (107, 167), inhibition of cell death (112), and decreased uptake of oxLDL in macrophages (105). Further, administration of immunoglobulins has shown promising results in animal studies (168). Another interesting possibility is to ameliorate atherosclerosis by modulating immune reactions against $\operatorname{HSP}(169,170)$.

\section{SUMMARY AND CONCLUSION}

Taken together, atherosclerosis and ensuing CVD represents major health problems in the developed world and especially so in patients with diabetes, where macro-vascular complications is a common problem. It has become clear that atherosclerosis on a background of diabetes or without is a chronic inflammation characterized by presence of activated immune competent cells throughout the lesions. Atherosclerosis in diabetes, though accelerated, does not seem to be very different from atherosclerosis in individuals without diabetes type 2, although certain diabetesspecific factors could contribute to pro-atherogenic immune activation and thus aggravate atherosclerosis and risk of CVD. In diabetes, reduction of endothelial NO-levels, systemic hyperglycemia if uncontrolled, generation of reactive oxygen species, oxidative stress, and increased LDL-oxidation, formation of AGEs, and increased circulating free fatty acids are factors that add to atherosclerosis and CVD risk. Potential triggers of immune activation in atherosclerosis in the general population (as well as among diabetics) include OxLDL and other LDL modifications and corresponding antibodies, possibly infections, high levels of heat shock protein antibodies, and low levels of natural antibodies as anti-PC. Clinical trials and other studies of immune-modulatory and antiinflammatory treatment in atherosclerosis and CVD are currently conducted but until such treatments are proven to be effective in humans, the exact role of immune reactions and inflammation in human atherosclerosis with or without type 2 diabetes remains to be clarified. 


\section{REFERENCES}

1. Beckman JA, Creager MA, Libby P. Diabetes and atherosclerosis: epidemiology, pathophysiology, and management. JAMA (2002) 287(19):2570-81. doi:10. 1001/jama.287.19.2570

2. Gao Y, Lu B, Sun ML, Hou $\mathrm{ZH}$, Yu FF, Cao HL, et al. Comparison of atherosclerotic plaque by computed tomography angiography in patients with and without diabetes mellitus and with known or suspected coronary artery disease. Am J Cardiol (2011) 108(6):809-13. doi:10. 1016/j.amjcard.2011.04.032

3. Puri R, Kataoka Y, Uno K, Nicholls SJ. The distinctive nature of atherosclerotic vascular disease in diabetes: pathophysiological and morphological insights. Curr Diab Rep (2012) 12(3):280-5. doi:10. 1007/s11892-012-0270-y

4. Cruz NG, Sousa LP, Sousa MO, Pietrani NT, Fernandes AP, Gomes $\mathrm{KB}$. The linkage between inflammation and Type 2 diabetes mellitus. Diabetes Res Clin Pract (2013) 99(2):85-92. doi:10.1016/j. diabres.2012.09.003

5. Frostegard J, Ulfgren AK, Nyberg P, Hedin U, Swedenborg J, Andersson U, et al. Cytokine expression in advanced human atherosclerotic plaques: dominance of pro-inflammatory (Th1) and macrophage-stimulating cytokines. Atherosclerosis (1999) 145(1):33-43. doi:10.1016/S00219150(99)00011-8

6. Purushothaman KR, Purushothaman M, Muntner P, Lento PA, O'Connor WN, Sharma SK, et al. Inflammation, neovascularization and intraplaque hemorrhage are associated with increased reparative collagen content: implication for plaque progression in diabetic atherosclerosis. Vasc Med (2011) 16(2):103-8. doi:10.1177/ 1358863X11402249

7. Burke AP, Kolodgie FD, Zieske A, Fowler DR, Weber DK, Varghese PJ, et al. Morphologic findings of coronary atherosclerotic plaques in diabetics: a postmortem study. Arterioscler Thromb Vasc Biol (2004) 24(7):1266-71. doi:10.1161/01.ATV.0000131783. 74034.97

8. Redgrave JN, Lovett JK, Syed AB, Rothwell PM. Histological features of symptomatic carotid plaques in patients with impaired glucose tolerance and diabetes (oxford plaque study). Cerebrovasc Dis
(2008) 26(1):79-86. doi:10.1159/ 000136900

9. Tabas I, Glass CK. Antiinflammatory therapy in chronic disease: challenges and opportunities. Science (2013) 339(6116):166-72. doi:10.1126/science.1230720

10. Libby P, Ridker PM, Hansson GK. Progress and challenges in translating the biology of atherosclerosis. Nature (2011) 473(7347):317-25. doi:10. 1038/nature10146

11. Sahathevan R, Brodtmann A, Donnan GA. Dementia, stroke, and vascular risk factors; a review. Int J Stroke (2012) 7(1):61-73. doi:10. 1111/j.1747-4949.2011.00731.x

12. Kallberg H, Ding B, Padyukov L, Bengtsson C, Ronnelid J, Klareskog $\mathrm{L}$, et al. Smoking is a major preventable risk factor for rheumatoid arthritis: estimations of risks after various exposures to cigarette smoke. Ann Rheum Dis (2011) 70(3):508-11. doi:10.1136/ ard.2009.120899

13. Frostegard J. Atherosclerosis in patients with autoimmune disorders. Arterioscler Thromb Vasc Biol (2005) 25(9):1776-85. doi:10.1161/01.ATV.0000174800. 78362.ec

14. Frostegard J. Cardiovascular co-morbidity in patients with rheumatic diseases. Arthritis Res Ther (2011) 13(3):225. doi:10.1186/ar3326

15. Tyrrell PN, Beyene J, Feldman BM, McCrindle BW, Silverman ED, Bradley TJ. Rheumatic disease and carotid intima-media thickness. A systematic review and metaanalysis. Arterioscler Thromb Vasc Biol (2010) 30(5):1014-26. doi:10. 1161/ATVBAHA.109.198424

16. Wasko MC, Kay J, Hsia EC, Rahman MU. Diabetes mellitus and insulin resistance in patients with rheumatoid arthritis: risk reduction in a chronic inflammatory disease. Arthritis Care Res (Hoboken) (2011) 63(4):512-21. doi:10.1002/ acr.20414

17. Chung CP, Oeser A, Solus JF, Gebretsadik T, Shintani A, Avalos I, et al. Inflammationassociated insulin resistance: differential effects in rheumatoid arthritis and systemic lupus erythematosus define potential mechanisms. Arthritis Rheum (2008) 58(7):2105-12. doi:10.1002/art.23600

18. Gonzalez-Gay MA, De Matias JM, Gonzalez-Juanatey C, GarciaPorrua C, Sanchez-Andrade A,
Martin J, et al. Anti-tumor necrosis factor-alpha blockade improves insulin resistance in patients with rheumatoid arthritis. Clin Exp Rheumatol (2006) 24(1):83-6.

19. Ferraz-Amaro I, Arce-Franco M, Muniz J, Lopez-Fernandez J, Hernandez-Hernandez V, Franco A, et al. Systemic blockade of TNFalpha does not improve insulin resistance in humans. Horm Metab Res (2011) 43(11):801-8. doi:10.1055/s-0031-1287783

20. Ursini F, Mauro D, Naty S, Gagliardi D, Grembiale RD. Improvement in insulin resistance after short-term treatment with abatacept: case report and short review. Clin Rheumatol (2012) 31(9):1401-2. doi:10.1007/s10067-012-2034-0

21. Mayerl C, Lukasser M, Sedivy R, Niederegger $H$, Seiler R, Wick G. Atherosclerosis research from past to present - on the track of two pathologists with opposing views, Carl von Rokitansky and Rudolf Virchow. Virchows Arch (2006) 449(1):96-103. doi:10. 1007/s00428-006-0176-7

22. Frostegard J. Rheumatic diseases: insights into inflammation and atherosclerosis. Arterioscler Thromb Vasc Biol (2010) 30(5):892-3. doi:10.1161/ ATVBAHA.110.204545

23. Jonasson L, Holm J, Skalli O, Bondjers G, Hansson GK. Regional accumulations of $\mathrm{T}$ cells, macrophages, and smooth muscle cells in the human atherosclerotic plaque. Arteriosclerosis (1986) 6(2):131-8. doi:10.1161/01.ATV.6.2.131

24. Frostegard J. Immunity, atherosclerosis and cardiovascular disease. BMC Med (2013) 11(1):117. doi:10.1186/1741-7015-11-117

25. Lichtman AH, Binder CJ, Tsimikas S, Witztum JL. Adaptive immunity in atherogenesis: new insights and therapeutic approaches. J Clin Invest (2013) 123(1):27-36. doi: 10.1172/JCI63108

26. Xu Q, Dietrich H, Steiner HJ, Gown AM, Schoel B, Mikuz G, et al. Induction of arteriosclerosis in normocholesterolemic rabbits by immunization with heat shock protein 65. Arterioscler Thromb (1992) 12(7):789-99. doi:10.1161/ 01.ATV.12.7.789

27. Palinski W, Miller E, Witztum JL. Immunization of low density lipoprotein (LDL) receptordeficient rabbits with homologous malondialdehyde-modified LDL reduces atherogenesis. Proc
Natl Acad Sci U S A (1995) 92(3):821-5. doi:10.1073/pnas.92. 3.821

28. Virella G, Lopes-Virella MF. Humoral immunity and atherosclerosis. Nat Med (2003) 9(3):243-4 author reply 244-245, doi:10.1038/nm0303-243

29. Maganto-Garcia E, Tarrio M, Lichtman AH. Mouse models of atherosclerosis. Curr Protoc Immunol (2012) 15:1-23. doi:10. 1002/0471142735.im1524s96

30. Matoba T, Sato K, Egashira K. Mouse models of plaque rupture. Curr Opin Lipidol (2013) 24(5):419-25. doi:10.1097/MOL. 0b013e3283646e4d

31. George J, Harats D, Gilburd B, Afek A, Shaish A, Kopolovic $\mathrm{J}$, et al. Adoptive transfer of beta(2)-glycoprotein Ireactive lymphocytes enhances early atherosclerosis in $\mathrm{LDL}$ receptor-deficient mice. Circulation (2000) 102(15):1822-27. doi:10.1161/01.CIR.102.15.1822

32. Zhou X, Robertson AK, Hjerpe C, Hansson GK. Adoptive transfer of $\mathrm{CD} 4+\mathrm{T}$ cells reactive to modified low-density lipoprotein aggravates atherosclerosis. Arterioscler Thromb Vasc Biol (2006) 26(4):864-70. doi:10.1161/ 01.ATV.0000206122.61591.ff

33. Ait-Oufella H, Salomon BL, Potteaux S, Robertson AK, Gourdy P, Zoll J, et al. Natural regulatory $\mathrm{T}$ cells control the development of atherosclerosis in mice. Nat Med (2006) 12(2):178-80. doi:10.1038/ $\mathrm{nm} 1343$

34. Tupin E, Nicoletti A, Elhage R, Rudling M, Ljunggren HG, Hansson GK, et al. CD1d-dependent activation of NKT cells aggravates atherosclerosis. J Exp Med (2004) 199(3):417-22. doi:10.1084/jem. 20030997

35. Cheng X, Yu X, Ding YJ, Fu QQ, Xie JJ, Tang TT, et al. The Th17/Treg imbalance in patients with acute coronary syndrome. Clin Immunol (2008) 127(1):89-97. doi:10.1016/ j.clim.2008.01.009

36. Li Q, Wang Y, Chen K, Zhou Q, Wei W. The role of oxidized lowdensity lipoprotein in breaking peripheral Th17/Treg balance in patients with acute coronary syndrome. Biochem Biophys Res Commun (2010) 394(3):836-42. doi: 10.1016/j.bbrc.2010.03.090

37. Gistera A, Robertson AK, Andersson J, Ketelhuth DF, Ovchinnikova O, Nilsson SK, et al. Transforming growth factor-beta signaling in $\mathrm{T}$ cells promotes 
stabilization of atherosclerotic plaques through an interleukin17-dependent pathway. Sci Transl Med (2013) 5(196):196ral00. doi:10.1126/scitranslmed.3006133

38. Giubilato S, Liuzzo G, Brugaletta S, Pitocco D, Graziani F, Smaldone C, et al. Expansion of CD4+CD28null T-lymphocytes in diabetic patients: exploring new pathogenetic mechanisms of increased cardiovascular risk in diabetes mellitus. Eur Heart J (2011) 32(10):1214-26. doi:10. 1093/eurheartj/ehq499

39. Feig JE, Feig JL. Macrophages, dendritic cells, and regression of atherosclerosis. Front Physiol (2012) 3:286. doi:10.3389/fphys. 2012.00286

40. Millonig G, Niederegger $\mathrm{H}$, Rabl W, Hochleitner BW, Hoefer D, Romani N, et al. Network of vascular-associated dendritic cells in intima of healthy young individuals. Arterioscler Thromb Vasc Biol (2001) 21(4):503-8. doi:10.1161/ 01.ATV.21.4.503

41. Yilmaz A, Lochno M, Traeg F, Cicha I, Reiss C, Stumpf C, et al. Emergence of dendritic cells in rupture-prone regions of vulnerable carotid plaques. Atherosclerosis (2004) 176(1):101-10. doi:10. 1016/j.atherosclerosis.2004.04.027

42. Liu P, Yu YR, Spencer JA, Johnson AE, Vallanat CT, Fong AM, et al. CX3CR1 deficiency impairs dendritic cell accumulation in arterial intima and reduces atherosclerotic burden. Arterioscler Thromb Vasc Biol (2008) 28(2):243-50. doi:10. 1161/ATVBAHA.107.158675

43. Bobryshev YV, Watanabe T. Ultrastructural evidence for association of vascular dendritic cells with T-lymphocytes and with Bcells in human atherosclerosis. $J$ Submicrosc Cytol Pathol (1997) 29(2):209-21.

44. Woollard KJ, Geissmann F. Monocytes in atherosclerosis: subsets and functions. Nat Rev Cardiol (2010) 7(2):77-86. doi:10.1038/ nrcardio.2009.228

45. Leitinger N, Schulman IG. Phenotypic polarization of macrophages in atherosclerosis. Arterioscler Thromb Vasc Biol (2013) 33(6):1120-6. doi:10.1161/ ATVBAHA.112.300173

46. Kovanen PT. Mast cells: multipotent local effector cells in atherothrombosis. Immunol Rev (2007) 217:105-22. doi:10.1111/j. 1600-065X.2007.00515.x

47. Willems S, Vink A, Bot I, Quax $\mathrm{PH}$, de Borst GJ, de Vries JP, et al.
Mast cells in human carotid atherosclerotic plaques are associated with intraplaque microvessel density and the occurrence of future cardiovascular events. Eur Heart J (2013). doi:10.1093/eurheartj/ eht186. [Epub ahead of print].

48. Fei GZ, Huang YH, Swedenborg J, Frostegard J. Oxidised LDL modulates immune-activation by an IL12 dependent mechanism. Atherosclerosis (2003) 169(1):77-85. doi: 10.1016/S0021-9150(03)00146-1

49. Frostegard J, Wu R, Giscombe R, Holm G, Lefvert AK, Nilsson J. Induction of T-cell activation by oxidized low density lipoprotein. Arterioscler Thromb (1992) 12(4):461-7. doi:10.1161/01.ATV. 12.4 .461

50. Frostegard J. Low level natural antibodies against phosphorylcholine: a novel risk marker and potential mechanism in atherosclerosis and cardiovascular disease. Clin Immunol (2010) 134(1):47-54. doi:10.1016/j.clim. 2009.08.013

51. Lopes-Virella MF, Virella G, Orchard TJ, Koskinen S, Evans RW, Becker DJ, et al. Antibodies to oxidized LDL and LDLcontaining immune complexes as risk factors for coronary artery disease in diabetes mellitus. Clin Immunol (1999) 90(2):165-72. doi:10.1006/clim.1998.4631

52. Camejo G, Lalaguna F, Lopez F, Starosta R. Characterization and properties of a lipoproteincomplexing proteoglycan from human aorta. Atherosclerosis (1980) 35(3):307-20. doi:10.1016/ 0021-9150(80)90129-X

53. Tabas I, Williams KJ, Boren J. Subendothelial lipoprotein retention as the initiating process in atherosclerosis: update and therapeutic implications. Circulation (2007) 116(16):1832-44. doi:10.1161/ CIRCULATIONAHA.106.676890

54. Frostegard J, Nilsson J, Haegerstrand A, Hamsten A, Wigzell H, Gidlund M. Oxidized low density lipoprotein induces differentiation and adhesion of human monocytes and the monocytic cell line U937. Proc Natl Acad Sci U S A (1990) 87(3):904-8. doi:10.1073/pnas.87.3.904

55. Berliner JA, Territo MC, Sevanian A, Ramin S, Kim JA, Bamshad B, et al. Minimally modified low density lipoprotein stimulates monocyte endothelial interactions. J Clin Invest (1990) 85(4):1260-6. doi: 10.1172/JCI114562
56. Elinder LS, Dumitrescu A, Larsson P, Hedin U, Frostegard J, Claesson HE. Expression of phospholipase A2 isoforms in human normal and atherosclerotic arterial wall. Arterioscler Thromb Vasc Biol (1997) 17(10):2257-63. doi: 10.1161/01.ATV.17.10.2257

57. Atout R, Karabina SA, Dollet S, Carreras M, Payre C, Andre P, et al. Human group $\mathrm{X}$ secreted phospholipase A2 induces dendritic cell maturation through lipoproteindependent and -independent mechanisms. Atherosclerosis (2012) 222(2):367-74. doi:10. 1016/j.atherosclerosis.2012.03.014

58. Huang YH, Schafer-Elinder L, Wu R, Claesson HE, Frostegard J. Lysophosphatidylcholine (LPC) induces proinflammatory cytokines by a platelet-activating factor (PAF) receptor-dependent mechanism. Clin Exp Immunol (1999) 116(2):326-31. doi:10. 1046/j.1365-2249.1999.00871.x

59. Goncalves I, Edsfeldt A, Ko NY, Grufman H, Berg K, Bjorkbacka $\mathrm{H}$, et al. Evidence supporting a key role of Lp-PLA2-generated lysophosphatidylcholine in human atherosclerotic plaque inflammation. Arterioscler Thromb Vasc Biol (2012) 32(6):1505-12. doi:10. 1161/ATVBAHA.112.249854

60. Frostegard J, Huang YH, Ronnelid J, Schafer-Elinder L. Plateletactivating factor and oxidized LDL induce immune activation by a common mechanism. Arterioscler Thromb Vasc Biol (1997) 17(5):963-8. doi:10.1161/01.ATV. 17.5.963

61. Watson $\mathrm{AD}$, Leitinger $\mathrm{N}$, Navab M, Faull KF, Horkko S, Witztum JL, et al. Structural identification by mass spectrometry of oxidized phospholipids in minimally oxidized low density lipoprotein that induce monocyte/endothelial interactions and evidence for their presence in vivo. $J$ Biol Chem (1997) 272(21):13597-607. doi:10. 1074/jbc.272.21.13597

62. Greig FH, Kennedy S, Spickett CM. Physiological effects of oxidized phospholipids and their cellular signaling mechanisms in inflammation. Free Radic Biol Med (2012) 52(2):266-80. doi:10.1016/ j.freeradbiomed.2011.10.481

63. Miller YI, Choi SH, Wiesner P, Fang L, Harkewicz R, Hartvigsen $\mathrm{K}$, et al. Oxidation-specific epitopes are danger-associated molecular patterns recognized by pattern recognition receptors of innate immunity. Circ Res
(2011) 108(2):235-48. doi:10. 1161/CIRCRESAHA. 110.223875

64. Birukov KG. Oxidized lipids: the two faces of vascular inflammation. Curr Atheroscler Rep (2006) 8(3):223-31. doi:10.1007/s11883006-0077- $\mathrm{x}$

65. Greenberg ME, Li XM, Gugiu BG, Gu X, Qin J, Salomon RG, et al. The lipid whisker model of the structure of oxidized cell membranes. $J$ Biol Chem (2008) 283(4):2385-96. doi:10.1074/jbc.M707348200

66. Bochkov VN, Oskolkova OV, Birukov KG, Levonen AL, Binder CJ, Stockl J. Generation and biological activities of oxidized phospholipids. Antioxid Redox Signal (2010) 12(8):1009-59. doi:10. 1089/ars.2009.2597

67. Levitan I, Volkov S, Subbaiah PV. Oxidized LDL: diversity, patterns of recognition, and pathophysiology. Antioxid Redox Signal (2010) 13(1):39-75. doi:10.1089/ ars.2009.2733

68. Salomon RG. Structural identification and cardiovascular activities of oxidized phospholipids. Circ Res (2012) 111(7):930-46. doi:10. 1161/CIRCRESAHA.112.275388

69. Weismann D, Binder CJ. The innate immune response to products of phospholipid peroxidation. Biochim Biophys Acta (2012) 1818(10):2465-75. doi:10.1016/j. bbamem.2012.01.018

70. Strom A, Fredrikson GN, Schiopu A, Ljungcrantz I, Soderberg I, Jansson B, et al. Inhibition of injury-induced arterial remodelling and carotid atherosclerosis by recombinant human antibodies against aldehyde-modified apoB-100. Atherosclerosis (2007) 190(2):298-305. doi:10.1016/j. atherosclerosis.2006.03.032

71. Jialal I, Devaraj S, Adams-Huet B, Chen X, Kaur H. Increased cellular and circulating biomarkers of oxidative stress in nascent metabolic syndrome. J Clin Endocrinol Metab (2012) 97(10):E1844-50. doi:10.1210/jc.2012-2498

72. Frostegard J, Wu R, Lemne C, Thulin T, Witztum JL, de Faire U. Circulating oxidized low-density lipoprotein is increased in hypertension. Clin Sci (Lond) (2003) 105(5):615-20. doi:10.1042/CS20030152

73. Hoogeveen RC, Ballantyne CM, Bang H, Heiss G, Duncan BB, Folsom AR, et al. Circulating oxidised low-density lipoprotein and intercellular adhesion molecule-1 and risk of type 2 diabetes mellitus: the Atherosclerosis Risk in 
Communities Study. Diabetologia (2007) 50(1):36-42. doi:10.1007/ s00125-006-0533-8

74. Lopes-Virella MF, Hunt KJ, Baker NL, Virella G, Moritz T. The levels of MDA-LDL in circulating immune complexes predict myocardial infarction in the VADT study. Atherosclerosis (2012) 224(2):526-31. doi:10. 1016/j.atherosclerosis.2012.08.006

75. Yusuf S, Hawken S, Ounpuu S, Dans T, Avezum A, Lanas F, et al. Effect of potentially modifiable risk factors associated with myocardial infarction in 52 countries (the INTERHEART study): case-control study. Lancet (2004) 364(9438):937-52. doi:10. 1016/S0140-6736(04)17018-9

76. Yanbaeva DG, Dentener MA, Creutzberg EC, Wesseling $G$, Wouters EF. Systemic effects of smoking. Chest (2007) 131(5):1557-66. doi:10.1378/chest.06-2179

77. Penn A, Snyder CA. Inhalation of sidestream cigarette smoke accelerates development of arteriosclerotic plaques. Circulation (1993) 88(4 Pt 1):1820-5. doi:10.1161/01. CIR.88.4.1820

78. Zhu BQ, Sun YP, Sievers RE, Isenberg WM, Glantz SA, Parmley WW. Passive smoking increases experimental atherosclerosis in cholesterol-fed rabbits. J Am Coll Cardiol (1993) 21(1):225-32. doi: 10.1016/0735-1097(93)90741-I

79. Gairola CG, Drawdy ML, Block AE, Daugherty A. Sidestream cigarette smoke accelerates atherogenesis in apolipoprotein $\mathrm{E}^{-/-}$mice. Atherosclerosis (2001) 156(1):49-55. doi: 10.1016/S0021-9150(00)00621-3

80. Morrow JD, Frei B, Longmire AW, Gaziano JM, Lynch SM, Shyr $\mathrm{Y}$, et al. Increase in circulating products of lipid peroxidation (F2-isoprostanes) in smokers. Smoking as a cause of oxidative damage. $N$ Engl $\mathrm{J} \mathrm{Med}$ (1995) 332(18):1198-203. doi:10. 1056/NEJM199505043321804

81. Kunitomo M, Yamaguchi Y, Kagota S, Yoshikawa N, Nakamura K, Shinozuka K. Biochemical evidence of atherosclerosis progression mediated by increased oxidative stress in apolipoprotein Edeficient spontaneously hyperlipidemic mice exposed to chronic cigarette smoke. J Pharmacol Sci (2009) 110(3):354-61. doi:10. 1254/jphs.09100FP

82. Andersson A, Bossios A, Malmhall C, Sjostrand M, Eldh M, Eldh BM, et al. Effects of tobacco smoke on IL-16 in CD8+ cells from human airways and blood: a key role for oxygen free radicals? Am J Physiol Lung Cell Mol Physiol (2011) 300(1):L43-55. doi:10. 1152/ajplung.00387.2009

83. Beckman JA, Goldfine AB, Gordon MB, Creager MA. Ascorbate restores endothelium-dependent vasodilation impaired by acute hyperglycemia in humans. Circulation (2001) 103(12):1618-23. doi: 10.1161/01.CIR.103.12.1618

84. Nishikawa T, Edelstein D, Du XL, Yamagishi S, Matsumura T, Kaneda Y, et al. Normalizing mitochondrial superoxide production blocks three pathways of hyperglycaemic damage. Nature (2000) 404(6779):787-90. doi:10. 1038/35008121

85. Laursen JB, Somers M, Kurz S, McCann L, Warnholtz A, Freeman BA, et al. Endothelial regulation of vasomotion in apoEdeficient mice: implications for interactions between peroxynitrite and tetrahydrobiopterin. Circulation (2001) 103(9):1282-8. doi:10. 1161/01.CIR.103.9.1282

86. Wang CC, Reusch JE. Diabetes and cardiovascular disease: changing the focus from glycemic control to improving long-term survival. Am J Cardiol (2012) 110(9 Suppl):58B-68. doi:10.1016/j. amjcard.2012.08.036

87. Shirwany NA, Zou MH. Vascular inflammation is a missing link for diabetes-enhanced atherosclerotic cardiovascular diseases. Front Biosci (2012) 17:1140-64. doi:10. 2741/3978

88. Yan SF, Ramasamy R, Schmidt AM. The receptor for advanced glycation endproducts (RAGE) and cardiovascular disease. Expert Rev Mol Med (2009) 11:e9. doi:10.1017/ S146239940900101X

89. Park L, Raman KG, Lee KJ, Lu Y, Ferran LJ Jr, Chow WS, et al. Suppression of accelerated diabetic atherosclerosis by the soluble receptor for advanced glycation endproducts. Nat Med (1998) 4(9):1025-31. doi:10.1038/2012

90. Soran H, Durrington PN. Susceptibility of LDL and its subfractions to glycation. Curr Opin Lipidol (2011) 22(4):254-61. doi:10. 1097/MOL.0b013e328348a43f

91. Virella G, Thorpe SR, Alderson NL, Stephan EM, Atchley D, Wagner F, et al. Autoimmune response to advanced glycosylation end-products of human LDL. J Lipid Res (2003) 44(3):487-93. doi:10.1194/jlr.M200370-JLR200
92. Bucala R, Makita Z, Koschinsky T, Cerami A, Vlassara H. Lipid advanced glycosylation: pathway for lipid oxidation in vivo. Proc Natl Acad Sci U S A (1993) 90(14):6434-8. doi:10.1073/pnas. 90.14 .6434

93. Dimitriadis E, Griffin M, Owens D, Johnson A, Collins P, Tomkin GH. Oxidation of low-density lipoprotein in NIDDM: its relationship to fatty acid composition. Diabetologia (1995) 38(11):1300-6. doi:10. 1007/BF00401762

94. Cummings MH, Watts GF, Umpleby AM, Hennessy TR, Naoumova R, Slavin BM, et al. Increased hepatic secretion of very-low-density lipoprotein apolipoprotein B-100 in NIDDM. Diabetologia (1995) 38(8):959-67. doi:10.1007/BF00400586

95. Uemura S, Matsushita H, Li W, Glassford AJ, Asagami T, Lee KH, et al. Diabetes mellitus enhances vascular matrix metalloproteinase activity: role of oxidative stress. Circ Res (2001) 88(12):1291-8. doi:10.1161/hh1201.092042

96. Vinik AI, Erbas T, Park TS, Nolan R, Pittenger GL. Platelet dysfunction in type 2 diabetes. Diabetes Care (2001) 24(8):1476-85. doi: 10.2337/diacare.24.8.1476

97. Mironova MA, Klein RL, Virella GT, Lopes-Virella MF. Antimodified LDL antibodies, LDLcontaining immune complexes, and susceptibility of LDL to in vitro oxidation in patients with type 2 diabetes. Diabetes (2000) 49(6):1033-41. doi:10.2337/diabetes.49.6.1033

98. Mironova M, Virella G, VirellaLowell I, Lopes-Virella MF. Anti-modified LDL antibodies and LDL-containing immune complexes in IDDM patients and healthy controls. Clin Immunol Immunopathol (1997) 85(1):73-82. doi:10.1006/clin.1997.4404

99. Virella G, Lopes-Virella MF. The pathogenic role of the adaptive immune response to modified LDL in diabetes. Front Endocrinol ( $\mathrm{Lau}$ sanne) (2012) 3:76. doi:10.3389/ fendo.2012.00076

100. Binder CJ. Naturally occurring IgM antibodies to oxidationspecific epitopes. Adv Exp Med Biol (2012) 750:2-13. doi:10.1007/9781-4614-3461-0_1

101. Shoenfeld Y, Wu R, Dearing LD, Matsuura E. Are anti-oxidized low-density lipoprotein antibodies pathogenic or protective? Circulation (2004) 110(17):2552-8.
doi:10.1161/01.CIR.0000143225. 07377.EA

102. Ajeganova S, Ehrnfelt C, Alizadeh R, Rohani M, Jogestrand T, Hafstrom I, et al. Longitudinal levels of apolipoproteins and antibodies against phosphorylcholine are independently associated with carotid artery atherosclerosis 5 years after rheumatoid arthritis onset - a prospective cohort study. Rheumatology (Oxford) (2012). doi:10.1093/rheumatology/ker204

103. Anania C, Gustafsson T, Hua X, $\mathrm{Su}$ J, Vikstrom M, de Faire U, et al. Increased prevalence of vulnerable atherosclerotic plaques and low levels of natural IgM antibodies against phosphorylcholine in patients with systemic lupus erythematosus. Arthritis Res Ther (2010) 12(6):R214. doi:10.1186/ ar3193

104. Caidahl K, Hartford M, Karlsson T, Herlitz J, Pettersson K, de Faire $\mathrm{U}$, et al. IgM-phosphorylcholine autoantibodies and outcome in acute coronary syndromes. Int $J$ Cardiol (2013) 167(2):464-9. doi: 10.1016/j.ijcard.2012.01.018

105. de Faire U, Su J, Hua X, Frostegard A, Halldin M, Hellenius ML, et al. Low levels of IgM antibodies to phosphorylcholine predict cardiovascular disease in 60-year old men: effects on uptake of oxidized LDL in macrophages as a potential mechanism. J Autoimmun (2010) 34(2):73-79. doi:10. 1016/j.jaut.2009.05.003

106. Su J, Georgiades A, Wu R, Thulin T, de Faire U, Frostegard J. Antibodies of IgM subclass to phosphorylcholine and oxidized LDL are protective factors for atherosclerosis in patients with hypertension. Atherosclerosis (2006) 188(1):160-6. doi:10.1016/ j.atherosclerosis.2005.10.017

107. Su J, Hua X, Concha H, Svenungsson E, Cederholm A, Frostegard J. Natural antibodies against phosphorylcholine as potential protective factors in SLE. Rheumatology (Oxford) (2008) 47(8):1144-50. doi:10.1093/ rheumatology/ken 120

108. Binder CJ, Horkko S, Dewan A, Chang MK, Kieu EP, Goodyear CS, et al. Pneumococcal vaccination decreases atherosclerotic lesion formation: molecular mimicry between Streptococcus pneumoniae and oxidized LDL. Nat Med (2003) 9(6):736-43. doi:10.1038/ nm876

109. Faria-Neto JR, Chyu KY, Li X, Dimayuga PC, Ferreira C, Yano J, 
et al. Passive immunization with monoclonal IgM antibodies against phosphorylcholine reduces accelerated vein graft atherosclerosis in apolipoprotein E-null mice. Atherosclerosis (2006) 189(1):83-90. doi:10.1016/j. atherosclerosis.2005.11.033

110. Caligiuri G, Khallou-Laschet $\mathrm{J}$, Vandaele M, Gaston AT, Delignat S, Mandet C, et al. Phosphorylcholine-targeting immunization reduces atherosclerosis. J Am Coll Cardiol (2007) 50(6):540-6. doi:10.1016/j.jacc.2006.11.054

111. de Faire U, Frostegard J. Natural antibodies against phosphorylcholine in cardiovascular disease. Ann N Y Acad Sci (2009) 1173:292-300. doi:10.1111/j. 1749-6632.2009.04748.x

112. Fiskesund R, Su J, Viksröm M, Faire UD, Frostegård J. Phosphorylcholine antibodies of the Group I idiotype inhibit cell death and, at high levels, are strong protection markers for atherosclerosis development, particularly when combined with other antibodies against modified LDL. Results Immunol (2012) 2:13-18. doi:10. 1016/j.rinim.2012.01.001

113. Gronwall C, Vas J, Silverman GJ. Protective roles of natural IgM antibodies. Front Immunol (2012) 3:66. doi:10.3389/fimmu. 2012.00066

114. Shapira Y, Poratkatz BS, Gilburd B, Barzilai O, Ram M, Blank M, et al. Geographical differences in autoantibodies and anti-infectious agents antibodies among healthy adults. Clin Rev Allergy Immunol (2012) 42(2):154-63. doi:10.1007/ s12016-010-8241-z

115. Agmon-Levin N, Bat-sheva PK, Barzilai O, Ram M, Lindeberg S, Frostegard J, et al. Antitreponemal antibodies leading to autoantibody production and protection from atherosclerosis in Kitavans from Papua New Guinea. Ann N Y Acad Sci (2009) 1173:675-82. doi:10. 1111/j.1749-6632.2009.04671.x

116. Elkan AC, Sjoberg B, Kolsrud B, Ringertz B, Hafstrom I, Frostegard J. Gluten-free vegan diet induces decreased LDL and oxidized LDL levels and raised atheroprotective natural antibodies against phosphorylcholine in patients with rheumatoid arthritis: a randomized study. Arthritis Res Ther (2008) 10(2):R34. doi:10. $1186 / \mathrm{ar} 2388$

117. Rahman I, Atout R, Pedersen NL, de Faire U, Frostegard J,
Ninio E, et al. Genetic and environmental regulation of inflammatory CVD biomarkers Lp-PLA2 and IgM anti-PC. Atherosclerosis (2011) 218(1):117-22. doi:10.1016/j.atherosclerosis. 2011.04.038

118. Engelbertsen D, Anand DV, Fredrikson GN, Hopkins D, Corder R, Shah PK, et al. High levels of IgM against methylglyoxalmodified apolipoprotein B100 are associated with less coronary artery calcification in patients with type 2 diabetes. J Intern Med (2012) 271(1):82-89. doi:10.1111/ j.1365-2796.2011.02411.x

119. Lopes-Virella MF, Virella G. Pathogenic role of modified LDL antibodies and immune complexes in atherosclerosis. $J$ Atheroscler Thromb (2013) 20:19281. doi:10. 5551/jat.19281

120. Eberle C, Merki E, Yamashita T, Johnson S, Armando AM, Quehenberger $\mathrm{O}$, et al. Maternal immunization affects in utero programming of insulin resistance and type 2 diabetes. PLoS One (2012) 7(9):e45361. doi:10.1371/journal. pone. 0045361

121. Rossmann A, Henderson B, Heidecker B, Seiler R, Fraedrich G, Singh $M$, et al. T-cells from advanced atherosclerotic lesions recognize hHSP60 and have a restricted T-cell receptor repertoire. Exp Gerontol (2008) 43(3):229-37. doi:10.1016/j.exger.2007.11.009

122. Knoflach M, Kiechl S, Mayrl B, Kind M, Gaston JS, van der Zee $\mathrm{R}$, et al. T-cell reactivity against HSP60 relates to early but not advanced atherosclerosis. Atherosclerosis (2007) 195(2):333-8. doi:10.1016/j.atherosclerosis. 2006.09.021

123. $\mathrm{Xu} \mathrm{Q}$, Willeit J, Marosi $\mathrm{M}$ Kleindienst R, Oberhollenzer F, Kiechl S, et al. Association of serum antibodies to heat-shock protein 65 with carotid atherosclerosis. Lancet (1993) 341 (8840):255-9. doi:10.1016/01406736(93)92613-X

124. Frostegard J, Kjellman B, Gidlund $\mathrm{M}$, Andersson $\mathrm{B}$, Jindal $S$, Kiessling R. Induction of heat shock protein in monocytic cells by oxidized low density lipoprotein. Atherosclerosis (1996) 121(1):93-103. doi:10.1016/00219150(95)05706-4

125. Frostegard J, Lemne C, Andersson B, van der Zee R, Kiessling $\mathrm{R}$, de Faire U. Association of serum antibodies to heat-shock protein 65 with borderline hypertension. Hypertension (1997) 29(1 Pt 1):40-44. doi:10.1161/01.HYP. 29.1.40

126. Rosenfeld ME, Campbell LA. Pathogens and atherosclerosis: update on the potential contribution of multiple infectious organisms to the pathogenesis of atherosclerosis. Thromb Haemost (2011) 106(5):858-67. doi:10.1160/TH11-06-0392

127. Shor A, Kuo CC, Patton DL. Detection of Chlamydia pneumoniae in coronary arterial fatty streaks and atheromatous plaques. S Afr Med J (1992) 82(3):158-61.

128. Saikku P, Leinonen M, Mattila K, Ekman MR, Nieminen MS, Makela PH, et al. Serological evidence of an association of a novel Chlamydia, TWAR, with chronic coronary heart disease and acute myocardial infarction. Lancet (1988) 2(8618):983-6. doi: 10.1016/S0140-6736(88)90741-6

129. Puolakkainen M, Kuo CC, Shor A, Wang SP, Grayston JT, Campbell LA. Serological response to Chlamydia pneumoniae in adults with coronary arterial fatty streaks and fibrolipid plaques. $J$ Clin Microbiol (1993) 31(8):2212-4.

130. Saikku P, Leinonen M, Tenkanen L, Linnanmaki E, Ekman MR, Manninen V, et al. Chronic Chlamydia pneumoniae infection as a risk factor for coronary heart disease in the Helsinki Heart Study. Ann Intern Med (1992) 116(4):273-8. doi:10.7326/00034819-116-4-273

131. O'Connor CM, Dunne MW, Pfeffer MA, Muhlestein JB, Yao L, Gupta S, et al. Azithromycin for the secondary prevention of coronary heart disease events: the WIZARD study: a randomized controlled trial. JAMA (2003) 290(11):1459-66. doi:10 1001/jama.290.11.1459

132. Grayston JT, Kronmal RA, Jackson LA, Parisi AF, Muhlestein JB, Cohen JD, et al. Azithromycin for the secondary prevention of coronary events. N Engl J Med (2005) 352(16):1637-45. doi:10. 1056/NEJMoa043526

133. Cannon CP, Braunwald E, McCabe $\mathrm{CH}$, Grayston JT, Muhlestein B, Giugliano RP, et al. Antibiotic treatment of Chlamydia pneumoniae after acute coronary syndrome. $N$ Engl $J$ Med (2005) 352(16):1646-54. doi:10.1056/NEJMoa043528

134. Lockhart PB, Bolger AF, Papapanou PN, Osinbowale O, Trevisan
M, Levison ME, et al. Periodontal disease and atherosclerotic vascular disease: does the evidence support an independent association? A scientific statement from the American Heart Association. Circulation (2012) 125(20):2520-44. doi:10.1161/ CIR.0b013e31825719f3

135. Chapple IL, Genco R. Diabetes and periodontal diseases: consensus report of the Joint EFP/AAP Workshop on Periodontitis and Systemic Diseases. J Clin Periodontol (2013) 40 Suppl 14:S106-2. doi: 10.1111/jcpe. 12077

136. Watanabe K, Petro BJ, Shlimon AE, Unterman TG. Effect of periodontitis on insulin resistance and the onset of type 2 diabetes mellitus in Zucker diabetic fatty rats. $J$ Periodontol (2008) 79(7):1208-16. doi:10.1902/jop.2008.070605

137. Preshaw PM, Alba AL, Herrera D, Jepsen S, Konstantinidis A, Makrilakis $\mathrm{K}$, et al. Periodontitis and diabetes: a two-way relationship. Diabetologia (2012) 55(1):21-31. doi:10.1007/s00125-011-2342-y

138. Fateh-Moghadam S, Bocksch W, Wessely R, Jager G, Hetzer R, Gawaz M. Cytomegalovirus infection status predicts progression of heart-transplant vasculopathy. Transplantation (2003) 76(10):1470-4. doi:10. 1097/01.TP.0000090163.48433.48

139. Melnick JL, Hu C, Burek J, Adam E, DeBakey ME. Cytomegalovirus DNA in arterial walls of patients with atherosclerosis. J Med Virol (1994) 42(2):170-4. doi:10.1002/ jmv. 1890420213

140. Streblow DN, Soderberg-Naucler C, Vieira J, Smith P, Wakabayashi E, Ruchti F, et al. The human cytomegalovirus chemokine receptor US28 mediates vascular smooth muscle cell migration. Cell (1999) 99(5):511-20. doi:10.1016/ S0092-8674(00)81539- 1

141. Stone AF, Mendall MA, Kaski JC, Edger TM, Risley P, Poloniecki J, et al. Effect of treatment for Chlamydia pneumoniae and Helicobacter pylori on markers of inflammation and cardiac events in patients with acute coronary syndromes: South Thames Trial of Antibiotics in Myocardial Infarction and Unstable Angina (STAMINA). Circulation (2002) 106(10):1219-23. doi:10.1161/01. CIR.0000027820.66786.CF

142. Mach F, Sukhova GK, Michetti M, Libby P, Michetti P. Influence of Helicobacter pylori infection during atherogenesis in vivo in 
mice. Circ Res (2002) 90(1):E1-4. doi:10.1161/hh0102.102270

143. Volzke H, Wolff B, Ludemann J, Guertler L, Kramer A, John U, Felix SB. Seropositivity for anti-Borrelia $\operatorname{IgG}$ antibody is independently associated with carotid atherosclerosis. Atherosclerosis (2006) 184(1):108-12. doi:10.1016/j.atherosclerosis. 2004.10.048

144. Toplak H, Haller EM, Lauermann T, Weber K, Bahadori B, Reisinger EC, et al. Increased prevalence of IgA-Chlamydia antibodies in NIDDM patients. Diabetes Res Clin Pract (1996) 32(1-2): 97-101. doi:10.1016/01688227(96)01216-8

145. Elkind MS. Infectious burden: a new risk factor and treatment target for atherosclerosis. Infect Disord Drug Targets (2012) 10(2):84-90. doi:10.2174/ 187152610790963519

146. Xia M, Guerra N, Sukhova GK, Yang K, Miller CK, Shi $\mathrm{GP}$, et al. Immune activation resulting from NKG2D/ligand interaction promotes atherosclerosis. Circulation (2011) 124(25):2933-43. doi:10.1161/ CIRCULATIONAHA.111.034850

147. Dandona P, Aljada A, Bandyopadhyay A. Inflammation: the link between insulin resistance, obesity and diabetes. Trends Immunol (2004) 25(1):4-7. doi:10.1016/j.it. 2003.10.013

148. Haeggstrom JZ, Funk CD. Lipoxygenase and leukotriene pathways: biochemistry, biology, and roles in disease. Chem Rev (2011) 111(10):5866-98. doi:10.1021/cr200246d

149. Qiu H, Gabrielsen A, Agardh HE, Wan $\mathrm{M}$, Wetterholm A, Wong $\mathrm{CH}$, et al. Expression of 5-lipoxygenase and leukotriene A4 hydrolase in human atherosclerotic lesions correlates with symptoms of plaque instability. Proc Natl Acad Sci U S A (2006) 103(21):8161-6. doi:10. 1073/pnas.0602414103

150. Manzi S, Meilahn EN, Rairie JE, Conte CG, Medsger TA Jr, Jansen-McWilliams L, et al. Age-specific incidence rates of myocardial infarction and angina in women with systemic lupus erythematosus: comparison with the Framingham Study. Am J Epidemiol (1997) 145(5):408-15. doi:10.1093/oxfordjournals.aje. a009122

151. Wajchenberg BL, Feitosa AC, Rassi N, Lerario AC, Betti RT. Glycemia and cardiovascular disease in type 1 diabetes mellitus. Endocr Pract (2008) 14(7):912-23. doi:10.4158/ EP.14.7.912

152. de Lorgeril M, Hamazaki T, Kostucki W, Okuyama H, Pavy B, McGill AT, et al. Is the use of cholesterol-lowering drugs for the prevention of cardiovascular complications in type 2 diabetics evidence-based? A systematic review. Rev Recent Clin Trials (2012) 7(2):150-7. doi:10.2174/ 157488712800100279

153. Khan MA, Gallo RM, Renukaradhya GJ, Du W, Gervay-Hague J, Brutkiewicz RR. Statins impair CD1d-mediated antigen presentation through the inhibition of prenylation. $J$ Immunol (2009) 182(8):4744-50. doi:10.4049/jimmunol.0804311

154. Wang CY, Liu PY, Liao JK. Pleiotropic effects of statin therapy: molecular mechanisms and clinical results. Trends $\mathrm{Mol} \mathrm{Med}$ (2008) 14(1):37-44. doi:10.1016/j. molmed.2007.11.004

155. Ridker PM, Danielson E, Fonseca FA, Genest J, Gotto AM Jr, Kastelein JJ, et al. Rosuvastatin to prevent vascular events in men and women with elevated C-reactive protein. N Engl J Med (2008) 359(21):2195-207. doi:10. 1056/NEJMoa0807646

156. Ridker PM. Moving beyond JUPITER: will inhibiting inflammation reduce vascular event rates? Curr Atheroscler Rep (2013) 15(1):295. doi:10.1007/s11883-012-0295-3

157. Micha R, Imamura F, Wyler von Ballmoos $\mathrm{M}$, Solomon $\mathrm{DH}$, Hernan MA, Ridker PM, et al. Systematic review and metaanalysis of methotrexate use and risk of cardiovascular disease. Am J Cardiol (2011) 108(9): 1362-70. doi:10.1016/j.amjcard. 2011.06.054

158. Bulgarelli A, Martins Dias AA, Caramelli B, Maranhao RC. Treatment with methotrexate inhibits atherogenesis in cholesterol-fed rabbits. $J$ Cardiovasc Pharmacol (2012) 59(4):308-14. doi:10.1097/FJC. 0b013e318241c385
159. Krishnan E, Lingala VB, Singh G. Declines in mortality from acute myocardial infarction in successive incidence and birth cohorts of patients with rheumatoid arthritis. Circulation (2004) 110(13):1774-9. doi:10.1161/01. CIR.0000142864.83780.81

160. Bernatsky S, Hudson M, Suissa S. Anti-rheumatic drug use and risk of hospitalization for congestive heart failure in rheumatoid arthritis. Rheumatology (Oxford) (2005) 44(5):677-80. doi:10.1093/ rheumatology/keh610

161. Qamar A, Rader DJ. Effect of interleukin 1beta inhibition in cardiovascular disease. Curr Opin Lipidol (2012) 23(6):548-53. doi:10.1097/ MOL.0b013e328359b0a6

162. Subbanagounder G, Leitinger $\mathrm{N}$, Shih PT, Faull KF, Berliner JA. Evidence that phospholipid oxidation products and/or plateletactivating factor play an important role in early atherogenesis: in vitro and in vivo inhibition by WEB 2086. Circ Res (1999) 85(4):311-18. doi:10.1161/ 01.RES.85.4.311

163. Ewing MM, de Vries MR, Nordzell M, Pettersson K, de Boer HC, van Zonneveld AJ, et al. Annexin A5 therapy attenuates vascular inflammation and remodeling and improves endothelial function in mice. Arterioscler Thromb Vasc Biol (2011) 31(1): 95-101. doi:10.1161/ATVBAHA. 110.216747

164. O'Donoghue ML, Braunwald E, White HD, Serruys P, Steg PG, Hochman J, et al. Study design and rationale for the stabilization of plaques using darapladibthrombolysis in myocardial infarction (SOLID-TIMI 52) trial in patients after an acute coronary syndrome. Am Heart J (2011) 162(4):613-19.e611. doi:10.1016/ j.ahj.2011.07.018

165. Fredrikson GN, Soderberg I, Lindholm M, Dimayuga P, Chyu KY, Shah PK, et al. Inhibition of atherosclerosis in apoE-null mice by immunization with apoB-100 peptide sequences. Arterioscler Thromb Vasc Biol (2003) 23(5):879-84. doi:10.1161/ 01.ATV.0000067937.93716.DB

166. BioInvent Announces Data From BI-204 Phase IIa Study on Stable Atherosclerotic Vascular Disease
(2012). Available from: http:// www.news-medical.net/news/ 20120711/BioInvent-announcesdata-from-BI-204-phase-IIastudy-on-stable-atheroscleroticvascular-disease.aspx

167. Chen Y, Khanna S, Goodyear CS, Park YB, Raz E, Thiel S, et al. Regulation of dendritic cells and macrophages by an antiapoptotic cell natural antibody that suppresses TLR responses and inhibits inflammatory arthritis. $J$ Immunol (2009) 183(2):1346-59. doi:10.4049/jimmunol.0900948

168. Nicoletti A, Kaveri S, Caligiuri G, Bariety J, Hansson GK. Immunoglobulin treatment reduces atherosclerosis in apo E knockout mice. J Clin Invest (1998) 102(5):910-8. doi:10.1172/JCI119892

169. Long J, Lin J, Yang X, Yuan D, Wu J, Li T, et al. Nasal immunization with different forms of heat shock protein-65 reduced highcholesterol-diet-driven rabbit atherosclerosis. Int Immunopharmacol (2012) 13(1):82-7. doi:10. 1016/j.intimp.2012.03.008

170. Murshid A, Gong J, Calderwood SK. The role of heat shock proteins in antigen cross presentation. Front Immunol (2012) 3:63. doi:10.3389/ fimmu.2012.00063

Conflict of Interest Statement: I am named as inventor on patent and patent applications relating to immunity and phospholipid antigens.

Received: 01 February 2013; accepted: 14 October 2013; published online: 29 October 2013.

Citation: Frostegård J (2013) Immune mechanisms in atherosclerosis, especially in diabetes type 2. Front. Endocrinol. 4:162. doi: 10.3389/fendo.2013.00162 This article was submitted to Systems and Translational Endocrinology, a section of the journal Frontiers in Endocrinology. Copyright (c) 2013 Frostegård. This is an open-access article distributed under the terms of the Creative Commons Attribution License (CC BY). The use, distribution or reproduction in other forums is permitted, provided the original author(s) or licensor are credited and that the original publication in this journal is cited, in accordance with accepted academic practice. No use, distribution or reproduction is permitted which does not comply with these terms. 